\title{
HUBUNGAN POLA MAKAN DAN AKTIVITAS FISIK DENGAN KEJADIAN HIPERTENSI DI KABUPATEN TULANG BAWANG
}

\author{
Tori Rihiantoro*, Muji Widodo** \\ *Dosen Jurusan Keperawatan Poltekkes Tanjungkarang \\ **Alumnus STIKES Mitra Lampung
}

\begin{abstract}
Hipertensi adalah suatu keadaan dimana seseorang mengalami peningkatan tekanan darah diatas normal, dimana tekanan darah dikategorikan tinggi 140/90 mmhg. Penyakit hipertensi disebabkan karena pola makan yang buruk dan kurangnya aktivitas fisik. 25 dari 32 penderita hipertensi mempunya kebiasaan pola makan buruk dan 23 dari 32 penderita hipertensi melakukan aktivitas fisik ringan <600Mets$\mathrm{min} /$ minggu. Tujuan dari penelitian ini adalah diketahui hubungan pola makan dan aktivitas fisik dengan kejadian hipertensi di Puskesmas Tulang Bawang I tahun 2017. Jenis penelitian adalah kuantitatif dengan metode pendekatan “ restrospektif” populasi penelitian adalah penderita hipertensi sejumlah 267 responden. Teknik sampel yang digunakan simple random sampling analisa data menggunakan uji chi square. Hasil penelitian menunjukan distribusi frekuensi hipertensi 32 responden $(50,0 \%)$ sebanyak 25 $(86,2 \%)$ mempunyai pola makan buruk, sebanyak $23(67,9 \%)$ melakukan aktivitas ringan < 600Mets$\mathrm{min} /$ minggu. Hasil uji chi square diperoleh data hubungan pola makan dengan kejadian hipertensi dengan p-value $=0,000$ dan ada hubungan aktivitas fisik dengan kejadian hipertensi dengan $\mathrm{p}$-value $=0,005$. Diharapkan pada pihak terkait khususnya Puskesmas Tulang Bawang I untuk menggalakan senam bersama bagi kelompok masyarakat beresiko hipertensi dan mengadakan penyuluhan tentang pentingnya pencegahan hipertensi dengan berbagai metode dan media.
\end{abstract}

Kata Kunci: Pola Makan, Aktivitas Fisik, Hipertensi

\section{LATAR BELAKANG}

Hipertensi merupakan salah satu penyakit yang mengakibatkan kesakitan yang tinggi. Hipertensi atau penyakit darah tinggi adalah gangguan pada pembuluh darah yang mengakibatkan suplai oksigen dan nutrisi yang dibawa oleh darah terhambat sampai ke jaringan tubuh yang membutuhkannya. Secara umum, hipertensi merupakan suatu keadaan tanpa gejala, dimana tekanan darah yang tinggi di dalam arteri menyebabkan meningkatnya risiko terhadap penyakitpenyakit yang berhubungan dengan kardiovaskuler seperti stroke, gagal ginjal, serangan jantung, dan kerusakan ginjal (Sutanto, 2010 dalam Widyaningrum, 2012).

World Health Organization (WHO) tahun 2013 menyebutkan bahwa penyakit hipertensi diketahui sering menimbulkan penyakit kardiovaskular, ginjal dan stroke. Telah terdapat 9,4 juta orang dari 1 milyar orang di dunia yang meninggal akibat gangguan kardiovaskular. Prevalensi hipertensi di negara maju maupun negara berkembang masih tergolong tinggi, adapun prevalensi hipertensi di negara maju adalah sebesar $35 \%$ dari populasi dewasa dan prevalensi hipertensi di negara berkembang sebesar $40 \%$ dari populasi dewasa. Adapun prevalensi hipertensi yang tertinggi terdapat di Amerika, yaitu sebesar $46 \%$ dari populasi dewasa dan di perkirakan 1 milyar penduduk didunia menderita hipertensi dan di prediksi pada tahun 2025 ada sekitar 29\% jiwa didunia yang akan menderita penyakit hipertensi (Julia. dkk, 2016).

Menurut National Health and Nutrition Examination Survey (NHNE) sedikitnya $30 \%$ penderita hipertensi tidak menyadari kondisi mereka, dan hanya 31 $\%$ pasien yang menyadari penyakitnya dan mencapai target di bawah 140/90 mmhg. Pada tahun 2006 American Hypertension Association melakukan penelitian dan di 
temukan hanya $68 \%$ penderita hipertensi yang tahu bahwa mereka menderita penyakit tersebut dan sisanya mengatakan tidak tahu (Triyanto, 2014).

Berdasarkan data epidemiologi tahun 2013 prevalensi hipertensi dinegara maju masih merupakan masalah global yang menjadi masalah kesehatan, di Amerika Serikat prevalensi hipertensi menempati urutan pertama penyebab kematian pada kelompok usia > 60 tahun yang berhubungan dengan penyakit degeneratif,sebesar 4 juta orang setiap tahun. Adapun di Rusia hipertensi pada klompok usia > 60 tahun sebesar 1-2 juta orang setiap tahun dan di Jepang hipertensi merupakan penyebab utama gangguan jantung koroner pada usia > 60 tahun (Hartono, 2013 dalam Arini. dkk, 2015).

Dari data NHNES tahun 2013 di perkirakan $30 \%$ penduduk di Amerika dengan jumlah penduduk ( \pm 50 juta jiwa) menderita tekanan darah tinggi $(\geq 140 / 90$ mmhg) dengan presentasi biaya kesehatan yang cukup besar setiap tahunya. Di Indonesia, dengan tingkat kesadaran akan kesehatan yang lebih rendah, dengan jumlah pasien yang cukup besar yang tidak menyadari dan mematuhi minum obat dengan kecenderungan perubahan sosial ekonomi dalam masyarakat Indonesia yang berdampak pada budaya dan gaya hidup masyarakat. Di dalam lingkup penyakit kardiovaskular, hipertensi menduduki peringkat pertama dengan jumlah penderita terbanyak (Triyanto, 2014)

Ada beberapa faktor penyebab terjadinya hipertensi, antara lain karakteristik individu ( usia, jenis kelamin, faktor genetik), pola makan,stres, gaya hidup (kurang aktivitas fisik) dan kebiasaan merokok. Ditemukan kecenderungan peningkatan prevalensi menurut peningkatan usia dan biasanya pada usia > 40 tahun. Bertambahnya umur maka resiko terkena hipertensi menjadi lebih besar sehingga prevalensi hipertensi dikalangan usia lanjut cukup tinggi, yaitu $40 \%$ dengan kematian sekitar diatas 65 tahun. Namun berat badan dan pola makan juga merupakan faktor determinan pada tekanan darah kebanyakan kelompok etnik disemua umur. Menurut National Institutes For Health USA (NIH,1998), prevalensi tekanan darah tinggi pada orang dengan Indeks Massa Tubuh (imt) >30 (obesitas ) adalah $38 \%$ untuk pria dan $32 \%$ untuk wanita, dibandingkan dengan prevalensi $18 \%$ untuk pria dan $17 \%$ untuk wanita bagi yang memiliki IMT <25 (status gizi normal menurut standar internasional). Dalam sebuah penelitian Harvard terhadap lebih dari 40.000 laki-laki, para peneliti menemukan bahwa asupan serat tinggi berpengaruh terhadap penurunan sekitar $40 \%$ resiko penyakit jantung koroner, dibandingkan dengan asupan rendah serat. Studi lain pada lebih dari 31.000 orang menemukan bahwa terjadi penurunan resiko penyakit jantung koroner nonfatal sebesar $44 \%$ dan mengurangi resiko penyakit jantung koroner fatal sebesar $11 \%$ bagi mereka yang makan roti gandum dibandingkan dengan mereka yang makan roti putih. Aktivitas fisik atau olahraga adalah salah satu cara untuk dapat menjaga tubuh tetap sehat, meningkatkan aktivitas fisik guan menghindari faktor resiko tulang kropos, dan mengurangi stres. Penelitian membuktikan bahwa orang yang berolahraga memiliki faktor resiko lebih rendah untuk menderita penyakit jantung, tekanan darah tinggi dan kolesterol tinggi. Orang yang beraktivitasnya rendah beresiko tekena hipertensi $30-50 \%$ dari pada yang aktif (Costas 2008, dalam Widyaningrum, 2012).

Prevalensi di Indonesia mencapai $31,7 \%$ dari populasi usia 18 tahun ke atas. Dari jumlah itu $60 \%$ penderita hipertensi mengalami komplikasi stroke dan sisanya mengalami penyakit jantung, gagal ginjal, serta kebutaan. Hipertensi juga sebagai penyebab kematian ke-3 setelah stoke dan tuberkulosis, jumlahnya mencapai $6,8 \%$ dari proporsi penyebab kematian pada semua umur di Indonesia (Kemenkes, 2014

Dari data dinas kesehatan Provinsi Lampung (2015) penyakit hipertensi menempati urutan pertama dari 10 penyakit terbesar. Data yang didapat adalah hipetrtensi (47 \%), ISPA (15\%), demam $(10 \%)$, penyakit telainga $(7 \%)$, 
dyspenia (6\%), diare (6\%), DM (4\%) Dan faringitis akut $(3 \%)$.

Puskesmas Tulang Bawang I merupakan salah satu Puskesmas dengan kasus hipertensi tertinggi dan selalu meningkat setiap tahunnya pada tahun 2014 sebesar 556 orang, meningkat di tahun 2015 sebesar 680 orang, dan kembali meningkat di tahun 2016 sebesar 737 orang. Sedangkat di tahun 2017 pada bulan Januari-Februari penderita hipertensi sudah mencapai 267 orang, sedangkan di puskesmas lain seperti di Puskesmas Banjar Margo penderita hipertensi dari bulan Januari-Februari hanya 132 orang.

Hipertensi adalah salah satu penyakit yang mengakibatkan kesakitan yang tinggi. Hipertensi atau penyakit darah tinggi adalah gangguan pada pembuluh darah yang mengakibatkan suplai oksigen dan nutrisi yang dibawa oleh darah terhambat sampai ke jaringan tubuh yang membutuhkannya. Secara umum, hipertensi merupakan suatu keadaan tanpa gejala, dimana tekanan darah yang tinggi di dalam arteri menyebabkan meningkatnya risiko terhadap penyakitpenyakit yang berhubungan dengan kardiovaskuler seperti stroke, gagal ginjal, serangan jantung, dan kerusakan ginjal (Sutanto, 2010 dalam Widyaningrum).

Menurut Triyanto, (2014) Hipertensi merupakan salah satu penyakit degeretatif. Umumnya tekanan darah bertambah secara perlahan dengan bertambahnya umur. Resiko untuk menderita hipertensi pada populasi $\geq 55$ tahun yang tadinya normal adalah 90\%. Sampai umur 55 tahun,lakilaki lebih banyak menderita hipertensi dibanding perempuan. Hipertensi ini pada dasarnya memiliki sifat yang cenderung tidak stabil dan sulit untuk di kontrol, maka dapat menyebabkan terjadinya infark jantung, gagal ginjal, stroke dan kerusakan mata.

Gaya hidup merupakan faktor penting yang mempengaruhi kehidupan masyarakat. Gaya hidup yang tidak sehat dapat menjadi penyebab terjadinya hipertensi misalnya aktivitas fisik, stres, dan Pola makan yang salah merupakan salah satu faktor resiko yang meningkatkan penyakit hipertensi. Faktor makanan modern sebagai penyumbang utama terjadinya hipertensi Kelebihan asupan lemak mengakibatkan kadar lemak dalam tubuh meningkat, terutama kolesterol yang menyebabkan kenaikan berat badan sehingga volume darah mengalami peningkatan tekanan yang lebih besar (Puspitorini. dkk, 2014 dalam Arini, 2015).

WHO (2011) menyatakan Faktor lain yang menyebabkan hipertensi adalah kurangnya aktivitas fisik. WHO menyatakan bahwa kurangnya aktivitas merupakan sebuah faktor resiko kunci utama terjadinya penyakit tidak menular seperti hipertensi, selain itu kurangnya aktifitas fisik juga merupakan faktor resiko utama ke empat kematian diseluruh dunia. Sekitar 3,2 juta orang meninggal setiap tahun karena masalah kurangnya aktivitas fisik (Wijaya. dkk. 2013)

Menurut Penelitian yang dilakukan oleh Siti Widyaningrum (2012), Rina Kundre, dkk (2015) dan Pujianta (2015) menyatakan bahwa ada hubungan pola makan dengan kejadian hipertensi. Sedangkan Rumsari Mutiarawati (2009), Hengli (2012) dan Mayasari, dkk (2015) menyatakan dalam penelitianya ada hubungan aktivitas fisik dengan kejadian hipertensi.

Berdasarkan data yang diperolah dari Puskesmas Tulang Bawang I diketahui hipertensi termasuk dalam 10 besar penyakit dan hipertensi berada di urutan ke-2 dengan jumlah penderita sebanyak 267 orang pada bulan Januari-Februari. Dengan kondisi jumlah penyakit hipertensi di Puskesmas Tulang Bawang I belum pernah di lakukan penelitian dan hal ini di dukung dari hasil wawancara yang di lakukan terhadap 25 orang pada tanggal 13-14 Maret 2017 terdapat 12 orang (48 $\%$ penderita menjawab memiliki kebiasaan sering mengkomsumsi makanan gurih, cepat saji, santan,gorengan dan juga daging, 9 orang (36\%) mengatakan kurang melakukan aktivitas atau pun olahraga secara teratur dan $4(16 \%)$ berusia $\geq 50$ tahun. 


\section{METODE}

Penelitian ini menggunakan disain penelitian survei analitik, dimana penelitian ini mencoba menggali fenomena tentang penyakit hipertensi yang terjadi di wilayah Puskesmas Tulang Bawang 1. Penelitian ini dilakukan dengan pendekatan case control, dimana peneliti berusaha melihat kebelakang (backward looking) terhadap beberapa faktor yang berhubungan dengan kejadian hipertensi meliputi pola makan dan aktivitas fisik.

Populasi dalam penelitian ini adalah penderita hipertensi yang berkunjung ke Puskesmas Tulang Bawang 1 selama dua bulan yang berjumlah 267 orang. Sedangkan populasi kontrol dalam penelitian ini adalah pasien yang datang berkunjung ke puskesmas tulang bawang yang tidak menderita penyakit hipertensi dan atau penyakit kardiovaskuler lainnya. Selanjutnya untuk menentukan sampel menggunakan teknik simple random sampling. Sedangkan untuk menentukan besar sampel digunakan rumus sampel menurut rumus Sujarweni (2014):

$$
n=\frac{(\mathrm{Z} \alpha+\mathrm{Z} \beta)^{2} \cdot \mathrm{p}(1-\mathrm{p})}{(\mathrm{P} 0-\mathrm{P} 1)^{2}}
$$

Berdasarkan hasil penghitungan diperoleh sampel sebesar 32 responden. Sehingga jumlah sampel keseluruhan sebesar 64 responden yang terbagi menjadi 32 responden untuk kasus hipertensi dan 32 responden untuk kontrol.

Data penelitian dikumpulkan dengan menggunakan kuesioner FFQ (Food Frequency Questionnaires) dan menggunakan kuesioner IPAQ (International Activity Quetionnaire. Dimana responden mendapatkan penjelasan tentang cara pengisisn kuesioner sebelum melakukan pengisian kuesioner. Kuesioner FFQ (food frequency questionnaires) untuk kuesioner frekuensi makan dan IPAQ ( International Physial Aktivity Quationnaire ) telah dilakukan uji validitas-reliabelitas dan dinyatakan valid dalam buku Gizi Kesehatan Masyarakat (Andri, dkk, 2009).

Data penelitian yang telah terkumpul, selanjutnya diolah dan dilakukan analisis data secara univariat dan bivariat menggunakan uji Chi Square dengan Confidence Interval (CI) sebesar $95 \%$.

\section{HASIL}

\section{Analisis Univariat}

Tabel 1: Distribusi Frekuensi Hipertensi (Kasus) Dan Tidak Hipertensi (Kontrol)

\begin{tabular}{lcc}
\hline \multicolumn{1}{c}{ Responden } & f & $\%$ \\
\hline Hipertensi (kasus) & 32 & 50 \\
\hline Tidak Hipertensi (kontrol) & 32 & 50 \\
\hline Jumlah & 64 & 100 \\
\hline
\end{tabular}

Tabel di atas menggambarkan bahwa dari total responden berjumlah 64 terdiri dari kasus sebanyak 32 responden $(50 \%)$ dan kontrol sebanyak 32 responden $(50 \%)$.

Tabel 2: Distribusi Frekuensi Pola Makan pada Kelompok Hipertensi (Kasus) dan Tidak Hipertensi (Kontrol)

\begin{tabular}{lllllll}
\hline \multirow{2}{*}{ Pola Makan } & $\begin{array}{c}\text { Hipertensi } \\
\text { (Kasus) }\end{array}$ & $\begin{array}{c}\text { Tidak } \\
\text { Hipertensi } \\
\text { (Kontrol) }\end{array}$ & Total \\
\cline { 2 - 7 } & $\mathrm{f}$ & $\%$ & $\mathrm{f}$ & $\%$ & $\mathrm{f}$ & \\
\hline Buruk & 25 & 86,2 & 4 & 13,8 & 29 & 100 \\
\hline Baik & 7 & 20 & 28 & 80 & 35 & 100 \\
\hline Jumlah & 32 & & 32 & & 64 & \\
\hline
\end{tabular}

Tabel di atas menggambarkan bahwa dari total 29 responden yang mempunyai pola makan buruk diperoleh data menderita hipertensi sebanyak 25 responden $(86,2 \%)$ dan yang tidak menderita hipertensi sebanyak 4 responen $(13,8 \%)$. Sedangkan dari total 35 responden yang mempuyai pola makan baik sebanyak 7 responden (20\%) menderita hipertensi dan yang tidak menderita hipertensi sebanyak 28 responden $(80 \%)$. 
Tabel 3: Distribusi Frekuensi Aktivitas Fisik pada Kelompok Hipertensi (Kasus) dan Tidak Hipertensi (Kontrol)

\begin{tabular}{lcccccc}
\hline & \multicolumn{2}{c}{$\begin{array}{c}\text { Hipertensi } \\
\text { Aktivitas Fisik }\end{array}$} & $\begin{array}{c}\text { Tidak } \\
\text { hipertensi } \\
\text { (kasus) }\end{array}$ & Total \\
& \multicolumn{1}{c}{$\begin{array}{c}\text { (kontrol) } \\
\text { R }\end{array}$} & $\%$ & $\mathrm{f}$ & $\%$ & $\mathrm{f}$ & $\%$ \\
\hline Ringan & 23 & 67,6 & 11 & 32,4 & 34 & 100 \\
\hline Sedang dan berat & 9 & 30,0 & 21 & 70,0 & 30 & 100 \\
\hline Jumlah & 32 & & 32 & & 64 & \\
\hline
\end{tabular}

Tabel di atas menggambarkan bahwa dari total 34 responden yang mempunyai aktivitas fisik ringan diperoleh data menderita hipertensi sebanyak 23 responden $(67,6 \%)$ dan yang tidak menderita hipertensi sebanyak 11 responen $(32,4 \%)$. Sedangkan dari total 30 responden yang mempuyai aktivitas fisik sedang dan berat sebanyak 9 responden (30\%) menderita hipertensi dan yang tidak menderita hipertensi sebanyak 21 responen $(70 \%)$

\section{Analisa Bivariat}

Tabel 4: Analisis Hubungan Pola Makan dengan Kejadian Hipertensi

\begin{tabular}{lcccccc}
\hline \multirow{2}{*}{ Pola Makan } & \multicolumn{2}{c}{$\begin{array}{c}\text { Hipertensi } \\
\text { (Kasus) }\end{array}$} & $\begin{array}{c}\text { Tidak } \\
\text { Hipertensi } \\
\text { (Kontrol) }\end{array}$ & Total \\
\cline { 2 - 7 } & $\mathrm{f}$ & $\%$ & $\mathrm{f}$ & $\%$ & $\mathrm{f}$ & $\%$ \\
\hline Buruk & 25 & 86,2 & 4 & 13,8 & 29 & 100 \\
\hline Baik & 7 & 20 & 28 & 80 & 35 & 100 \\
\hline p-value & 0,000 & & & & \\
\hline OR (95\% CI) & 4.310 & $(2.187-8,494)$ & & \\
\hline
\end{tabular}

Berdasarkan tabel di atas diketahui dari 29 responden yang pola makannya buruk terdapat 25 responden $(86,2 \%)$ menderita hipertensi dan 4 responen $(13,8 \%)$ tidak menderita hipertensi. Sedangkan dari 35 responden yang pola makannya baik terdapat 7 responden (20\%) menderita hipertensi dan 28 responden $(80 \%)$ tidak menderita hipertensi.

Hasil uji statistik diperoleh nilai $p$ value $=0,000$. Hal ini menunjukan adanya hubungan antara pola makan dengan kejadian hipertensi. Hasil analisis juga menggambarkan nilai $\mathrm{OR}=4.31 \quad(2,187$ $8,494)$ yang berarti orang yang pola makannya buruk beresiko untuk menderita hipertensi 4,31 kali dibandingkan dengan yang pola makanya baik.

Tabel 5: Analisis Hubungan Aktivitas Fisik dengan Kejadian Hipertensi

\begin{tabular}{|c|c|c|c|c|c|}
\hline \multirow[t]{2}{*}{$\begin{array}{l}\text { Aktivitas } \\
\text { Fisik }\end{array}$} & \multicolumn{3}{|c|}{$\begin{array}{cc}\text { Hipertensi } & \text { Tidak } \\
\text { (Kasus) } & \begin{array}{c}\text { Hipertensi } \\
\text { (Kontrol) }\end{array}\end{array}$} & \multicolumn{2}{|c|}{ Total } \\
\hline & f $\%$ & $\mathrm{f}$ & $\%$ & $\mathrm{f}$ & $\%$ \\
\hline Ringan & $23 \quad 67,6$ & 11 & 32,4 & 34 & 100 \\
\hline Sedang dan berat & 930,0 & 21 & 70 & 30 & 100 \\
\hline p-value & \multicolumn{5}{|c|}{0,005} \\
\hline OR $(95 \% \mathrm{CI})$ & \multicolumn{5}{|c|}{$2,255(1,245-4,084)$} \\
\hline
\end{tabular}

Dari tabel di atas diketahui dari total 34 responden yang aktivitas fisiknya ringan terdapat 23 responden $(67,6 \%)$ menderita hipertensi dan 11 responen $(32,4 \%)$ tidak menderita hipertensi. Sedangkan dari total 30 responden yang aktivitas fisiknya sedang dan berat terdapat 9 responden $(30 \%)$ menderita hipertensi dan 21 responen $(70 \%)$ tidak menderita hipertensi.

Hasil uji statistik di peroleh nilai $p$ value $=0,005$. Hal ini menunjukan adanya hubungan antara aktivitas fisik dengan kejadian hipertensi. Hasil analisis juga menjelaskan nilai OR=2,255 $(1,245-4,084)$ yang berarti responden yang melakukan aktivitas fisik ringan beresiko untuk menderita hipertensi sebesar 2,26 kali dibandingkan dengan yang melakukan aktivitas fisik sedang dan berat.

\section{PEMBAHASAN}

\section{Hipertensi}

Penelitian ini menggambarkan dari 64 responden sebanyak $32(50 \%)$ adalah penderita hipertensi. Berdasarkan data Riskesdas tahun 2013 angka prevalensi hipertensi di Indonesia mencapai 31,7\% dari populasi usia 18 tahun ke atas. Sebanyak $60 \%$ penderita hipertensi tersebut mengalami komplikasi stroke dan sisanya mengalami penyakit jantung, gagal ginjal, serta kebutaan. Hipertensi menjadi 
penyebab kematian ketiga setelah stoke dan tuberkulosis yang angkanya mencapai $6,8 \%$ dari proporsi penyebab kematian pada semua umur di Indonesia. Sedangkan berdasarkan data pada dinas kesehatan Provinsi Lampung tahun 2015 hipertensi menempati urutan pertama dari 10 penyakit terbesar.

Angka kejadian hipertensi ini mempunyai kecenderungan terus meningkat dari tahun ke tahun baik dalam sekala nasional maupun daerah. Demikian juga dengan kejadian hipertensi di Puskesmas Tulang Bawang I, dimana angka kejadiannya selalu meningkat setiap tahunnya. Pada tahun 2014 sebesar 556 orang, meningkat menjadi 680 orang pada tahun 2015, dan kembali meningkat pada tahun 2016 sebesar 737 orang.

Secara umum, hipertensi merupakan suatu keadaan tanpa gejala, dimana tekanan darah yang tinggi di dalam arteri menyebabkan meningkatnya risiko terhadap penyakit-penyakit yang berhubungan dengan kardiovaskuler seperti stroke, gagal ginjal, serangan jantung, dan kerusakan ginjal (Sutanto, 2010 dalam Widyaningrum).

Menurut Triyanto (2014) hipertensi merupakan salah satu penyakit degeretatif. Umumnya tekanan darah bertambah secara perlahan dengan bertambahnya umur. Resiko untuk menderita hipertensi pada populasi $\geq 55$ tahun yang tadinya normal adalah 90\%. Sampai umur 55 tahun,lakilaki lebih banyak menderita hipertensi dibanding perempuan. Hipertensi ini pada dasarnya memiliki sifat yang cenderung tidak stabil dan sulit untuk di kontrol, maka dapat menyebabkan terjadinya infark jantung, gagal ginjal, stroke dan kerusakan mata.

\section{Pola Makan}

Hasil penelitian menggambarkan dari jumlah 32 hipertensi (kasus) di Puskesmas Tulang Bawang I sebagian besar memiliki kebiasaan pola makan buruk yaitu sebanyak 25 orang dan 7 orang mempunyai pola makan baik.
Persagi, 2003 dalam Widyaningrum 2012 menyatakan Pola makan terdiri dari frekuensi makan, jenis makanan dan tingkat konsumsi.

Frekuensi makan adalah jumlah makan dalam sehari-hari secara alamiah makanan diolah dalam tubuh melalui alatalat pencernaan mulai dari mulut sampai usus halus. Lama makanan dalam lambung tergantung sifat dan jenis makanan. Jika dirata-rata, umumnya lambung kosong antara 3-4 jam (Persagi, 2003 dalam Widyaningrum, 2012).

Jenis makanan adalah variasi bahan makanan yang kalau dimakan, dicerna,dan diserap akan menghasilkan paling sedikit susunan menu sehat dan seimbang menyediakan variasi makanan merupakan salah stau cara untuk menghilangkan rasa bosan. Seseorang akan merasa bosan apabila dihidangkan menu yang itu-itu saja, sehingga mengurangi selera makan (Persagi, 2003 dalam Widyaningrum, 2012).

$\begin{array}{ccr}\text { Menyusun } & \text { hidangan } & \text { sehat } \\ \text { memerlukan } & \text { keterampilan } & \text { dan }\end{array}$
pengetahuan gizi dengan berorientasi pada pedoman 4 sehat 5 sempurna terdiri dari bahan pokok (nasi, ikan, sayuran, buah dan susu). Variasi menu yang tersusun oleh kombinasi bahan makanan yang diperhitungkan dengan tepat akan memberikan hidangan sehat baik secara kualitas maupun kuantitas. Teknik pengolahan makanan adalah guna memperoleh intake yang baik dan bervariasi (Persagi, 2003 dalam Widyaningrum, 2012).

Pengertian tingkat konsumsi adalah kualitas dan kuantitas hidangan. Kualitas hidangan menunjukkan adanya semua zat gizi yang diperlukan tubuh di dalam susunan hidangan dan perbandingan yang satu terhadap yang lain. Kuantitas menunjukkan kwantum masing-masing zat gizi terhadap kebutuhan tubuh. Jika susunan hidangan memenuhi kebutuhan tubuh, baik dari sudut kualitas atau kuantitas, maka tubuh akan mendapatkan kondisi kesehatan gizi yang sebaikbaiknya. 
Aktivitas Fisik

Hasil penelitian mengambarkan dari jumlah 32 hipertensi (kasus) diperoleh sebanyak 23 responden melakukan aktivitas fisik ringan. Sedangkan dari jumlah 32 tidak hipertensi (kontrol) diketahui melakukan aktivitas fisik ringan sebanyak 11 responden.

WHO (2011) menyatakan bahwa aktivitas fisik adalah gerakan fisik yang dilakukan oleh otot tubuh dan sistem penunjangnya dari setiap gerakan tubuh yang dihasilkan oleh otot rangka yang memerlukan pengeluaran energi. Kurangnya aktivitas fisik merupakan faktor resiko independent untuk penyakit kronis, dan secara keseluruhan diperkirakan menyebabkan kematian global.

\section{Hubungan Pola Makan dengan Kejadian Hipertensi}

Hasil penelitian menunjukan adanya hubungan pola makan dengan kejadian hipertensi. Berdasarkan nilai $\mathrm{OR}=4,31$, maka berarti pola makan buruk beresiko mengalami hipertensi 4,31 kali dibandingkan dengan pola makan baik.

Hasil penelitian tersebut sejalan dengan penelitian Emerita Stefany (2012) dimana terdapat hubungan pola makan, dengan kejadian hipertensi pada pra lansia dan lansia. Hasil penelitian Devi Catur (2015) juga mendukung hasil penelitian ini, dimana terdapat hubungan konsumsi makanan dengan kejadian hipertensi. Demikian juga dengan penelitian Arifin, dkk (2016) yang menyatakan bahwa dari beberapa faktor yang berhubungan dengan kejadian hipertensi pada kelompok lanjut usia, salah satunya adalah faktor pola makan. Hal yang sama juga pada penelitian Andrian dkk 2016 tentang hubungan konsumsi makanan dengan kejadian hipertensi.

Pola makan adalah salah satu faktor penyebab terjadinya berbagai penyakit seperti salah satunya adalah hipertensi. salah satu cara untukmengurangi terjadinya penyakit hipertensi adalah dengan menjaga pola makan dengan baik yaitu mengurangi asupan banyak lemak dan asupan garam disamping itu perlu meningkatkan makan buah dan sayur.

Faktor-faktor yang mempengaruhi pola makan menurut Wulandari \& Susilo (2011), yaitu usia, pendidikan, budaya, pengalaman, pendapatan, pekerjaan dan agama.

Penjelasan di atas dan berdasarkan pengisian kuesioner diketahui bahwa responden mempunyai tingkat konsumsi makanan mengandung tinggi natrium dan juga lemak, dimana natrium yang sifatnya menahan air sehingga menambah beban darah masuk ke jantung dan berakibat pada kenaikan tekanan darah. Sementara lemak dapat menyebabkan pembuluh darah menjadi tebal atau menjadi endapaan keras yang tidak normal pada dinding arteri sehingga pembuluh darah mendapat pukulan paling berat, jika tekanan darah terus menerus tinggi dan tidak berubah sehingga saluran darah tersebut menjadi sempit dan aliran darah menjadi tidak lancar dan dapat menyebabkan penyakit arteosklorosis.

Pembahasan di atas dan berdasarkan masalah yang terjadi pada responden hasil pengisian quesioner diketahui kurangnya pengetahuan dan informasi tentang pola makan adalah salah satu penyebab terjadinya hipertensi. Maka peneliti menyimpulkan bahwa pola makan penyebab terjadinya hipertensi.

\section{Hubungan Aktivitas Fisik Dengan Kejadian Hipertensi}

Hasil penelitian menunjukan adanya hubungan aktivitas fisik dengan kejadian hipertensi. Diperoleh juga nilai $\mathrm{OR}=2,255$ yang berarti responden yang melakukan aktivitas fisik ringan beresiko mengalami hipertensi sebesar 2,255 kali dibandingkan dengan yang melakukan aktivitas fisik sedang dan berat.

Hal ini didukung oleh penelitian Lilianty Fauzi (2014) yang menyebutkan bahwa terdapat hubungan yang signifikan antara aktivitas fisik dengan kejadian hipertensi. Penelitian Agustina (2013) juga memperkuat hasil penelitian, dimana hasil penelitian menyimpulkan terdapat hubungan aktivitas fisik dengan tekanan 
darah pada penderita hipetensi. Hasil penelitian Andria (2013) juga menyimpulkan adanya hubungan antara prilaku olahraga dengan tingkat hipertensi pada lanjut usia. Demikian juga dengan penelitian Rumsari (2009) yang menyimpulkan bahwa terdapat hubungan antara riwayat aktivitas fisik dengan kejadian hipertensi pada usia 45-54 tahun.

Aktivitas fisik umumnya diartikan sebagai gerakan tubuh yang ditimbulkan oleh otot-otot skeletal dan mengakibatkan pengeluaran energi.Bagi yang mempunyai satu atau lebih faktor resiko hipertensi, aktifitas fisik dapat mencegah terjadinya peningkatan tekanan darah. Bagi penderita hipertensi ringan, aktifitas fisik dapat mengendalikan tekanan darah, sehingga mungkin tidak diperlukan lagi peengobatan farmakologis. Olahraga secara teratur idealnya 3-5 kali dalam seminggu dan minimal setengah jam setiap sesi dengan instensitas sedang. Olahraga yang dianjurkan bagi penderita hipertensi yang sifatnya ringan seperti jalan kaki, joging, bersepeda (Sustranim, 2004 dalam Sulistiyowati, 2009)

Menurut WHO,2011 Aktivitas fisik adalah gerakan fisik yang dilakukan oleh otot tubuh dan sistem penunjangnya dari setiap gerakan tubuh yang dihasilkan oleh otot rangka yang memerlukan pengeluaran energi. Kurangnya aktivitas fisik merupakan faktor resiko independent untuk penyakit kronis, dan secara keseluruhan diperkirakan menyebabkan kematian global.

Aktivitas fisik mempengaruhi stabilitas tekanan darah. Pada orang yang tidak aktif melakukan kegiatan fisik cenderung mempunyai frekuensi denyut jantung yang lebih tinggi. Hal tersebut mengakibatkan otot jantung bekerja lebih keras pada setiap kontraksi. Makin keras usaha otot jantung dalam memompa darah, makin besar pula tekanan yang dibebankan pada dinding arteri sehingga meningkatkan tahanan perifer yang menyebabkan kenaikan tekanan darah. WHO merekomendasikan untuk melakukan aktivitas fisik dengan intensitas sedang selama 30 menit/ hari dalam 1 minggu atau
20 menit/ hari selama 5 hari dalam satu minggu dengan intensitas berat untuk mendapatkan hasil yang optimal dari aktivitas fisik atau olahraga.Para ahli epdemiologi membagi aktivitas fisik kedalam 2 kategori, yaitu aktivitas fisik terstruktur (kegiatan olahraga) dan aktivitas fisik tidak terstruktur (kegitan sehari-hari seperti berjalan, bersepeda dan bekerja (Fatmah, 2011 dalam Lilianty Fauzi, 2014).

Dari pembahasan di atas dan masalah yang terjadi pada responden diketahui kurangnya penyuluhan dari tenaga kesehatan khususnya pihak Puskesmas Tulang Bawang I sehingga responden tidak mengetahui pentingnya melakukan aktivitas fisik. Dengan masalah yang terjadi maka peneliti menyimpulkan bahwa ada hubungan aktivitas fisik dengan kejadian hipertensi

\section{KESIMPULAN}

Hasil penelitian menyimpulkan bahwa ada hubungan antara pola makan dengan kejadian hipertensi di Puskesmas Tulang Bawang I, dimana pola makan buruk beresiko untuk menderita hipertensi 4,31 kali lebih besar dibandingkan dengan pola makan baik. Hasil penelitian juga menyimpulkan bahwa ada hubungan antara aktivitas fisik dengan kejadian hipertensi di Puskesmas Tulang Bawang I, dimana responden yang melakukan aktivitas fisik ringan beresiko mengalami hipertensi sebesar 2,255 kali lebih besar dibandingkan dengan yang melakukan aktivitas fisik sedang dan berat.

Berdasarkan kesimpulan di atas makan penulis menyarankan agar Puskesmas Tulang Bawang I meningkatkan upaya promotif dan preventif, melalui kegiatan senam maupun olehraga bagi kelompok masyarakat yang beresiko mengalami hipertensi. Selain itu juga dapat dilakukan dengan upaya deteksi dini penderita hipertensi dan penyuluhan tentang pentingnya pencegahan hipertensi dengan berbagai macam metode dan media. 


\section{DAFTAR PUSTAKA}

Arini. dkk, 2015. Hubungan Gaya Hidup Dan Pola Makan Dengan Kejadian Hipertensi Pada Lansia Di Kelurahan Sawangan Baru Kota Depok Tahun 2015. Jurnal. Jakarta

Dinkes Provinsi Lampung, 2015. Profil Kesehatan Provinsi Lampung.

Julia, Giront Linda.dkk, 2016. Hubungan Antara Kebiasaan Merokok Dan Aktivitas Fisik Dengan Kejadian Pada Pasien Poliklinik Umum Di Puskesmas Ranotama Weru Kota Manado Tahun 2016.

Fauzi, Lilianty. 2014. Hubungan Aktivitas Fisik Dengan Kejadian Hipertensi Pada Pasien Rawat Jalan Di Poliklinik Telkomedika Health Center Bandar Lampung. Tesis. Stikes Mitra Lampung

Pujianta, 2015. Hubungan Pola Makan Dengan Tingkat Hipertensi Lanjut Usia Di Posyandu Pucanganom Rongkop Gunungkidul Tahun 2015.Jurnal.stikes aisyiyah.Yogyakarta
Puskesmas Tulang Bawang I, 2017. Data 10 Penyakit Terbesar Di Puskesmas Tulang Bawang I. Tulang bawang.

Sulistiyowati, 2009. Faktor-Faktor Yang Berhubungan Dengan Kejadian Hipertensi Di Kampung Botton Kelurahan Magelang Kec. Mage;Lang Tengah Tahun 2009. Skripsi.semarang

Triyanto, 2014. Pelayanan Keperawatan Bagi Penderita Hipertensi Secara Terpadu. Yogyakarta : Graha Ilmu.

Widyaningrum, 2012 Hubungan Antara Konsumsi Makanan dengan Kejadian Hipertensi Pada Lansia (Studi di UPT Pelayanan Sosial Lanjut Usia Jember). Sripsi.Universitas Jember

WHO, 2013. 1 miliar orang di dunia alami hipertensi. www.voaindonesia.com/ a/who-1-miliar-orang-alami-hiper tensi/1636680. diakses pada april $\underline{2017}$

Wijaya. Dkk, 2013. KMB I ( Keperawatan Medikal Bedah (Keperawatan Dewasa )). Numbed.

Wulandari \& Susilo, 2011. Cara Jitu Mengatasi Hipertensi. Yogyakarta : Andi Offset. 